\title{
ДУХОВНО-ІНТЕЛЕКТУАЛЬНА КОМПОНЕНТА УПРАВЛІНСЬКОЇ КОМПЕТЕНТНОСТІ ВИКЛАДАЧА ЗАКЛАДУ ВИЩОЇ ОСВІТИ
}

\section{Доценко Д. Г.}

здобувач другого (магістерського) рівня вищої освіти кафедри освітології та іноваційної педагогіки, Харківський національний педагогічний

університет імені Г. С. Сковороди, м. Харків, Україна

У статті йдеться про формування управлінської компетентності викладача закладу вищої освіти. Зазначено, щу духовно-інтелектуальний розвиток є складовою управлінської компетентності викладача закладу вищої освіти.

Ключові слова: управління, компетентність, викладач, інтелект, духовність, заклад вищиої освіти.

The article describes the formation of managerial competence of a higher education institution 's teacher. It is noted that spiritual and intellectual development is a component of managerial competence of a teacher of higher education.

Key words: management, competence, teacher, intellect, spirituality, institution of higher education.

Кінець XIX - початок XX століття став початком формування нових концептуальних підходів до змісту освіти, його критеріїв та методів. Засобом розвитку такої освіти є компетентнісний підхід, який $€$ предметом наукових пошуків таких вчених як Б.Вульфсон, Дж.Равен, О. Пометун, О.Овчарук, А.Хуторський.

3 огляду на те, що сучасна культура управління в галузі освіти дуже тісно пов'язана з рефлексією та соціально-цивілізаційними змінами, а питання духовно-інтелектуальної компетентності викладача закладу вищої освіти відіграє важливу роль у системі його управлінських компетенцій.

Виходячи 3 нашого розуміння компетентності як особистісної якості викладача, що проявляється у його здатності до виконання певних функцій, визначених професійною діяльністю або вимогами посади, можна зробити висновок, що мистецтво управління - це здатність співробітництва з людьми (здобувачами освіти, колегами), узгодження їх діяльності, уміння створювати позитивні відносини у колективі. Є таке прислів’я «Зустрічають по одежі, проводжають по 
розуму». Воно достатньо чітко підкреслює не тільки розумові здібності, а й уміння співвідносити їх з внутрішнім світом людини, в нашому випадку викладача. Професійні знання, інтелектуальність повинні підкреслювати не тільки унікальність викладача, але також його здатність приймати неординарні, а головне ефективні рішення. Викладач вищої щколи повинен за рахунок духовних категорій розкрити сутність свого рішення, його вплив на формування позитивного результату розвитку особистості.

Рівень професійного мислення викладача (маючи на увазі управлінський) пов' язаний з якостями його розуму, глибиною проникнення у зміст ситуації або явища, гнучкістю прийняття рішення, критичності, доказовості, обгрунтування своєї точки зору, об'єктивності. А все це в значній мірі залежить від духовної складової особистості викладача, його можна сказати, духовного кредо.

У цьому процесі значне місце займає сприймання викладачем дійсності, iї оцінка через призму особистих духовних цінностей і принципів, здатність аналізу і синтезу подій, тобто глибина інтелектуального сприймання. «Чим багатіше сприймання, чим воно більш розвинене, тим більш багате і розвинене мислення, більш сильний його вплив на інтереси особистості» (А. Браткін).

На основі уявлень та різноманітних знань, які безпосередньо пов'язані з духовно-інтелектуальною компонентою управлінської компетентності викладача, функціонує і пов'язана з цим комплексна уява, яка є важливою якістю менеджера освіти. Уява, представляючи слухачам або колегам у конкретно-образній формі той стан, до якого прагне викладач, стимулює розвиток відповідних інтересів, підтримує і посилює їх, приводить до їхнього закріплення, їхньої стійкості.

Таким чином, духовно-інтелектуальна компонента управлінської компетентності викладача закладу освіти є важливою компонентою у структурі підготовки і прийняття управлінських рішень, їх реалізації у колективі. 